\title{
Observations and insights on pasture persistence in New Zealand
}

\author{
P.M.S. LANE \\ Ballance Agri-Nutrients Ltd, PO Box 390, Cambridge, 3450 \\ mlane@ballance.co.nz
}

\begin{abstract}
This essay contains personal observations and interpretations by the author on the persistence of pastures in the northern North Island. Key pasture stress factors are identified as the increase of farming intensity over the past two decades, the impact of pasture renewal techniques and the role of pasture species on insect pest (particularly black beetle and clover root weevil) interactions.
\end{abstract}

Keywords: insect pests, soil fertility, pasture renewal, cultivars, endophyte,

\section{Introduction}

These comments on pasture persistence are based largely on my observations and those conveyed to me by the many farmers met in the course of my career. Also included are findings from a survey conducted by Ballance Agri-Nutrients in March 2008 of 34 farms in which 102 paddocks were sampled in the Waikato region (Willoughby \& Lane 2008). I have been involved in research and product development all my working life, trialled many products and techniques on farms throughout NZ, and over the past 20 or so years, worked on hundreds of properties and met many hundreds of farmers. A key focus of my work has been looking for pastoral solutions, from pasture renewal to weed management and cropping. A recurring theme has been that pastures do not appear to last as long as they did in the past.

This is not a scientific paper. It is presented to serve as a vital component of the scientific process, that of interpreting the observations that lead to the questions that form testable scientific hypotheses.

Not all pastoral farmers perceive that they have a problem with pasture persistence. As a broad observation, farmers on farms under-stocked by today's criteria, and on farms in the more southern regions do not have pasture persistence issues at the same level as farmers managing intensively farmed pastures in the northern regions. In the northern regions, temperatures are generally higher, weather patterns and soil types differ, but these factors have been consistent over the past 100 years, so there is little point in looking for explanations here. So what has changed? They can be summarised in two points:

1. Farming intensity.
2. Pasture species, cultivars \& endophytes.

\section{Farming intensity}

Pastoral farming, particularly dairying, has intensified in the past 20 years. For example, on Waikato dairy farms which comprise $22 \%$ of pastoral farms in the region, stocking rate has increased from 2.7 cows/ha in 1996/97 to 3.02 cows/ha in 2009 (Environment Waikato 2008). Nitrogen (N) fertiliser use has increased from 25 $\mathrm{kg} \mathrm{N} / \mathrm{ha} / \mathrm{yr}$ in the $1990 \mathrm{~s}$ to $150 \mathrm{~kg} \mathrm{~N} / \mathrm{ha} / \mathrm{yr}$ in 2007 and more bought-in feed is used (400 kg DM/ha in 1998 to $1400 \mathrm{~kg} \mathrm{DM} / \mathrm{ha}$ in 2007). Outputs have also steadily increased in the Waikato with milk solids/ha lifting by 62\% between 1998 and 2007 (Environment Waikato 2008).

Increased stock densities have meant that stresses on pastures such as from stock trampling and shortened rotations have not only increased, but added greater burden to the soil by way of increased compaction and faecal matter.

Modern pasture management protocols set up to supply high quality forage, do not facilitate natural grass reseeding and that is another aspect that needs to be considered with respect to pasture sustainability. The movement away from primarily summer-made hay followed 25 years ago, to spring-made silage, has also decreased the reseeding that used to naturally occur on farms.

Putting aside the obvious impact of more hooves resulting in more damage (crushing) of pasture preventing it being eaten, the more long-term impact is in the form of increased soil compaction. Our survey in 2008 (Willoughby \& Lane 2008) revealed that 55\% of paddocks were highly compacted with an average of $28 \%$ (range $0 \%$ to $80 \%$ ) of ryegrass plants 'pulled' post grazing. A large number of paddocks had up to $80 \%$ of ryegrass plants pulled out, laying on the surface. This had not occurred in the paddocks that had been developed using "no-tillage" techniques; light and medium soil compaction was identified in $29 \%$ and $16 \%$ of paddocks respectively with $1 \%$ and $8 \%$ plant pulling respectively. Fig. 1 well illustrates an effect of soil compaction on the root growth of pasture species. The shortened root system makes plants vulnerable to pulling and reduces their capacity to source water and nutrients. 
The intensification of farming has meant more cultivation of the soil as more crops are grown and pastures renovated to keep production levels high. Cultivation is disruptive to the soil ecosystem. For example, while cultivation reduces grass grub (Costelytra zealandica) numbers, the disease organisms that moderate grass grub populations are also destroyed by cultivation, resulting in high grub numbers that threaten pastures typically $2-3$ years later (East \& Willoughby 1983). Cultivation also reduces earthworm populations. Healthy soils contain more than 500 earthworms $/ \mathrm{m}^{2}$ that play a vital role in maintaining soil structure and distributing water and nutrients. The survey revealed (Willoughby \& Lane 2008) that earthworm populations 1-year post cultivation in soils categorised as low, medium and high compaction, were $102 / \mathrm{m}^{2}, 74 / \mathrm{m}^{2}$ and $34 / \mathrm{m}^{2}$ respectively. Populations had generally doubled by 3 years post-cultivation.

Pasture stressors are dynamic especially with pest complexes varying with species and density over time (Bell et al. 2006). For example numbers of Tasmanian grass grub (Aphodius tasmaniae) vary from year to year depending, amongst a variety of factors, on climatic conditions. Add clover root weevil (Sitona lepidus) into the mix with its impact on white clover (Trifolium repens) $\mathrm{N}$ fixation, and the dynamic from a pasture management point of view becomes complex. Add root pruning from grass grub and black beetle (Heteronychus arator) larvae and the pasture may become a candidate for palliative care.

A logical response is to question the cultivation techniques we use to establish crops and renew pasture. The practice of 'no till' may have a significant role to play in restoring and maintaining soil structure especially in the light soils that reflect more severe impacts from compaction. It is interesting to note that in the course of the 2008 survey, three pastures established through a completely "no-till" cropping and re-grassing process had markedly higher root penetration and volume (Willoughby \& Lane 2008). Pasture tolerance of black beetle larval feeding was also observed to be greater and grass grub populations were maintained at relatively low levels. While it is logical that more robust plants will be better able to withstand pest attack, these observations warrant confirmation and quantification of their value in a formal scientific investigation. The opportunity for long-term assessment of this is now available with the establishment of AgResearch's Tokanui Research Farm near Te Awamutu.

\section{Pasture species, cultivars \& endophytes}

While the mainstay for pastoral farming continues to be ryegrass (Lolium perenne) and white clover, the robustness of the currently available cultivars and endophytes to handle the demands of today's farming must be questioned.

With recognition of the role of endophytic fungi in protecting pasture grasses against some insect pests (Popay \& Hume 2011, this volume) research has focused on the introduction of endophytes with reduced animal toxicity and to target protection against specific pests. Perennial ryegrass has been a popular target for novel endophyte introductions with some success for specific pests (e.g. Argentine stem weevil (Listronotus bonariensis). However, insect pests, particularly in the northern North Island, don't cooperate by infesting pastures one species at a time. They occur in complexes that reflect numerous factors including pasture age, composition, soil type, management, latitude and altitude.

For example black beetle and grass grub often coexist in northern North Island pastures. Singularly, the species may not pose serious problems for pasture persistence. However, with the black beetle larvae attacking ryegrass roots in January, followed soon after by grass grub larvae continuing the pruning and adult black beetle attacking the foliage of susceptible plants throughout most of the rest of the year, is it any wonder that our pastures have a persistence problem! It then becomes a numbers game from the pest status aspect. How much damage can the plant withstand? If it is already compromised by a deficient rooting system as previously described, or by lack of soil moisture, then the last thing a farmer would wish to inflict on his pastures would be any further advantage to the pests? Perhaps not an appropriate time to introduce low residual grazing techniques, softer endophytes, and reduced $\mathrm{N}$ application?

We know a lot about the biology of black beetle from the work of the scientists Doug King (King et al. 1981a) and Richard Watson (Watson \& Wrenn 1979). Paspalum (Paspalum dilatatum) was a favoured diet, the plant offered shelter and increased fecundity to black beetle (King et al.1981b) and they favoured it to the extent that it was virtually eliminated from Waikato pastures by the 1990s (arguably 'Roundup ${ }^{\circledR}$ ' also contributed here!) and is likely part of the reason black beetle as a pasture pest became insignificant in the following years. Also, through the 1990s, pasture renewal was largely a single autumn spray and drill programme driven by Dexcel's success at limiting turnip cropping as a result of their "More Summer Milk" programme. New perennial pastures were also being sown with "high endophyte" (now called "wild type endophyte") ryegrasses. These grasses produced high levels of ergovaline, limiting adult black beetle winter feeding and subsequent survival/egg laying.

So why has black beetle become such a pest in the 
Waikato in the past 8 years? Because farmers were sold on the idea of sowing ryegrasses with AR1 endophytes. The first indication of a problem was observed in 2003, when AR1 pastures were seen to fail due to black beetle damage, on the light soils near Matamata, within 2 years of sowing. As a result of this observation, one seed company reduced promotion of AR1 in the black beetle zone, in favour of their other endophyte lines. Observations in subsequent years proved the validity of this decision. Large areas of 2- and 3-year old AR1 ryegrass pasture began to fail. Failed AR1 pastures have even been observed in Taranaki, where black beetle had previously been observed but not associated with pasture failure. Extensive field observations led to low level promotions against AR1 at field days, this position being supported with real data as a result of the Ballance Agri-Nutrients funded "Big Dig" project of 2008 (Willoughby \& Lane 2008) where 100 core samples were assessed from 100 paddocks, each being 1,2 or 3 years post cultivation.

A summary of the data from the Big Dig was presented to DairyNZ and AgResearch science staff, during the winter of 2008. Essentially, black beetle numbers were recorded at pasture damaging levels in $39 \%$ of year 1 , $78 \%$ of year 2 and $91 \%$ of year- 3 pastures sampled in the Waikato. Pastures lost to black beetle were recorded as far south as Litchfield in the Waikato region, outside its previously reported range (King et al. 1981b). In these pastures there was a prevalence of perennial ryegrass containing the endophyte AR1. Also, annual and Italian ryegrasses were promoted widely during this period to 'repair' damaged pasture. This leads to the inference that pasture species contribute to the high numbers of black beetle observed, as AR1 endophyte gives only slight control of black beetle and commercial annual/ Italian ryegrasses do not contain endophyte. Other observations, where 20-year-old and older pastures had low black beetle numbers compared to the destroyed 3-year-old AR1 pasture in the adjacent paddock, led to the conclusion that unwittingly, farmers had created an ideal environment for black beetle to flourish.

Commercial interests with respect to the promotion of ryegrass varieties may have served to cloud the issue of the nature of insect resistance conferred by endophyte. While AgResearch have been clear that AR1 offered limited tolerance to black beetle, their successful promotion focused on the benefits of AR1 to the grazing animal. Some commercial interests in other sectors downplayed the lack of black beetle tolerance, with AR1 promoted long after it was clearly implicated in reduced pasture persistence. This conflicting advice to farmers continued from 2003 to 2010 and has been to the detriment of farmers and the farm services industries as a whole. Selfish commercial interests were put before the (expected) long-term investments farmers were making in pasture renewal, leading to many farmers losing their investment and their pasture development programmes being set back years.

To some the issue was obvious, however others failed to react to the evidence in front of them. Seed companies switched their seedlines available in the northern North Island to largely AR1, limiting farmer choice. Their representatives promoted AR1 vigorously as late as autumn of 2010. Retail organisations filled their stores with primarily AR1 grasses, leading to retail representatives selling AR1 grasses into paddocks where AR1 had already failed due to black beetle. Research organisations failed to act on the evidence presented. This has truly been one of those situations where it was better for farmers to ignore the hype, and do as they always did.

What should change in the future? More time is required to prove products. The rush to get sales returns should not overshadow the science. Royalties paid to researchers send the wrong signals and should be discontinued. New products, especially long-term investment products, need to be monitored for some time to ensure they meet expectations in the long-term. To demonstrate this point we could ask: how many perennial pasture trials currently operating in $\mathrm{NZ}$ are funded for more than 3 years? I think we know the answer.

Some good has come out of the fiasco:

- Recognition that farmers and suppliers need to know more about pasture pests.

- That treated seed is essential.

- That we all need to have a greater understanding of and take more responsibility for long-term decisions like "what pasture variety?".

It is also hoped that the key parameters of the "Programmed Approach" be adopted; these are that two autumn sprays be used to control perennial weed species, and a period of time elapse without clover to control clover-specific pests (Lane et al. 2009).

White clover has been a mainstay of New Zealand pastures for decades. This legume provides complementary growth patterns to perennial ryegrass, enhances the animal dietary component of pastures with high levels of feed value and protein, and is the host to symbiotic bacteria (Rhizobium trifolii) that fix atmospheric $\mathrm{N}$ making it available to other plants. White clover is a survivalist, increased hoof numbers may sever the stolons but these usually survive individually. The varroa mite (Varroa destructor) has decimated feral honey bee hives (Apis melifera) in New Zealand but seed setting over many years has ensured a soil seed bank of around $40 \mathrm{~kg} / \mathrm{ha}$ (Chapman $\&$ Anderson 1987) which contributes to white clover re-establishment. White clover is under attack from a range of pests, including insects, nematodes, and 
Figure 1: Impact of soil compaction on root growth of perennial ryegrass.

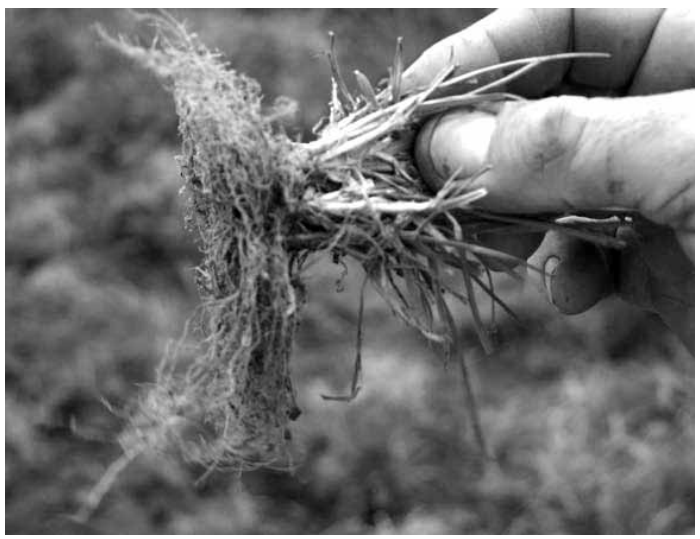

diseases, but probably the most damaging is clover root weevil. Unless we find a way to protect white clover from the clover root weevil (but see Gerard et al. 2009) we face the prospect of reducing the contribution of this valuable species as a viable component of grazed pastures. Clover root weevil larvae consume the Rhizobium root nodules reducing clover $\mathrm{N}$ fixation and then eat the roots of white clover. Sufficiently stressed, the plant reduces seed production and adopts a smallleaved prostrate form away from the tongues of grazing cows (Brock et al. 1988).

In Waikato pasture in 2008 we recorded nodulation on $13 \%$ and $8 \%$ of white clover plants from year-2 and year-3 pastures respectively (Willoughby \& Lane 2008). (Some of these pastures were nearly $100 \%$ clover ground cover due to black beetle). Put another way, white clover plants had virtually no nodules, whereas prior to the arrival of clover root weevil we would have expected to find $70 \%$ to $100 \%$ of white clover plants in pasture with nodules. In the survey, seasonally dry conditions in many of the pastures sampled may in part have explained this observation. However the extensive evidence of clover root weevil implicated this obligate clover pest in the removal of nodules. If this was the case, is reduced clover $\mathrm{N}$ as a result of clover root weevil infestation, responsible, at least in part, for decline in pasture longevity?

\section{Some questions}

As intended, the observations outlined above pose questions rather than answers.

In response to observations that perennial pastures today are not as sustainable because they are not persisting, farmers need answers to the following questions. This list is intended to form the basis of ongoing discussion.

1. How are the cultivation/crop establishment techniques we use affecting pasture longevity?
2. What are the cultivation/crop establishment practices precipitating compaction in soils?

3. Which soils are most vulnerable to these practices?

4. What role does 'no till' have in creating more sustainable pastures in New Zealand?

5. Recognising the value of earthworms in nutrient cycling and soil health, are there cultivation methods/equipment that facilitate the survival of earthworms?

6. What might we do to reintroduce earthworms to paddocks where numbers have declined?

7. Are the endophytes available conveying the advantages farmers need for sustainable perennial pastures?

8. What is the process required to return black beetle ravaged AR1 pastures back to persistent high performing novel endophyte pastures?

9. What is the impact of clover root weevil on clover $\mathrm{N}$ fixation?

10. How much bagged $\mathrm{N}$ is required to overcome the effects of clover root weevil and do we need to be smarter about application technologies?

11. When will the white clover soil seed bank 'run out'?

12. Black beetle and grass grub are not going to go away, so how can NZ pasture grasses be made resistant to root grazing organisms such as these... is it time to look at biotechnology solutions?

13. What is the impact of drilling phosphate with the seed on pasture establishment, seeding rate and ultimately pasture longevity?

14. Has sowing technology made our current seeding rates obsolete in some instances?

15. How might we better manage animal waste to augment soils rather than threaten them?

16. Is black beetle an increasing problem because too many of our pasture ryegrass cultivars are a favourable host?

\section{Conclusions}

Ten years of farmer observation of declining pasture persistence through northern parts of NZ perhaps means that farmers should be brought into the loop to identify some solutions. Science has not served them particularly well of late when it comes to this issue and there is the chance that healthy scepticism will turn into distrust. I suggest that a suitable time line would be to firstly identify the reasons for poor persistence, secondly to develop the technology to overcome the identified issues, and thirdly set up an appropriate extension programme to help good adoption. Does this 
sound like something from the past? Perhaps. There was a time when farmers had interactive access to research through regional research farms and scientists who worked alongside advisors to disseminate information.

To retain farming as an economically, social and environmentally sustainable industry the issues to do with pasture sustainability must be addressed. I think answers will be found in how we manage our soils and in the pasture establishment process. Ideally, pasture longevity problems will decline by maintaining soil structure and the pest/predator balance with low soil disturbance techniques such as:

- no-tillage,

- using suitable ryegrass endophytes,

- sowing fewer seeds/ha but giving each seed greater opportunity by coating with insecticide and placing phosphate nearby,

- treating the new pasture as a crop.

With science driven by the needs of both the farming and wider community and the implementation of improved technology currently available, progress towards more sustainable pastures can be made.

\section{ACKNOWLEDGEMENTS}

I acknowledge the support and contributions of my friend Bruce Willoughby in the preparation of this paper.

\section{REFERENCES}

Bell N.L.; Hardwick S.; Eerens J.P.J.; James T.K. 2006. Managing biological succession in intensive pastoral ecosystems for improved production and sustainability. New Zealand Plant Protection 59: 271-280.

Brock, J.L.; Hay, M.J.M.; Thomas, V.J.; Sedcole, J.R. 1988. Morphology of white clover (Trifolium repens L.) plants in pasture under intensive sheep grazing. Journal of Agricultural Science 111: 273-283.

Chapman D.F.; Anderson, C.B. 1987. Natural reseeding and Trifolium repens demography in grazed hill pastures. 1. Flowerhead appearance and fate, and seed dynamics. Journal of Applied Ecology 24: 1025-1035.

East, R.; Willoughby, B.E. 1983. Grass grub (Costelytra zealandica) population collapse in the northern North Island. New Zealand Journal of Agricultural Research 26:381-390.

Environment Waikato 2008. The condition of rural water and soil in the Waikato region - risks and opportunities.

Gerard, P.J.; Hardwick, S.; Addison, P.J.; Willoughby B.E.; Goldson S.L. 2009. The bionomics of an invasive species Sitona lepidus during its establishment in New Zealand. Bulletin of Entomological Research
100: 339-346.

King P.D.; Mercer C.F.; Meekings J.S. 1981a. Ecology of Black Beetle, Heteronychus arator (Coleoptera: Scarabaeidae) - population modelling. New Zealand Journal of Agriculture 24: 99-105.

King P.D.; Mercer C.F; Meekings J.S. 1981b. Ecology of Black Beetle, Heteronychus arator (Coleoptera: Scarabaeidae) - population studies. New Zealand Journal of Agriculture 24: 87-975.

Lane, P.M.S; Addison, P.J; Van Plateringen, M.J. 2009. The Programmed approach to pasture renewal and cropping. Proceedings of the New Zealand Grassland Association 71: 89-92.

Popay, A.J.; Hume, D.E. 2011. Endophytes improve ryegrass persistence by controlling insects. Pasture persistence. Grassland Research and Practice Series 15: 149-156.

Watson, R.N; Wrenn, N.R. 1979. An association between Paspalum dilatatum and black beetle in pasture. Proceedings of the New Zealand Grassland Association 41: 96-103.

Willoughby, B.; Lane, M. 2008. Identifying the risk grass grub (Costelytra zealandica) poses to high value pastures on light ash based soils in the Waikato region. Ballance Agri-Nutrients report. 
